\title{
Influence of Location in Nutrient Composition of Larvae Cuetlas (Arsenura polyodonata C) Insect Consume in Mexico
}

\author{
Virginia Melo-Ruiz*, Karina Sánchez-Herrera, Daniel Ruiz-Juárez, Mónica Gutiérrez-Rojas and Francisco López \\ Naranjo
}

Universidad Autónoma Metropolitana, México City, México

*Corresponding Author: Virginia Melo-Ruiz, Universidad Autónoma Metropolitana, México City, México.

Received: August 30, 2019; Published: September 13, 2019

\begin{abstract}
Edible insects intake is a cultural tradition in México, this food contain nutrients in several species, that can be used for human consumption, however availability and nutrient composition depend of the biotic and abiotic environment conditions. Cuetlas common name of larvae stage of the butterfly (Arsenura polyodonata $\mathrm{C}$ ) insect consumed, in different zones of Puebla State were studied [1]. The aim of this paper was to investigate, insect availability, and assess nutrient composition of Cuetlas consume in Atlixco, Puebla State. Insects gathered July 2018 (1), and in September 2018 (2) at Atlixco central zone of Puebla State, to analyze moisture and macronutrients content of raw insect sample, according AOAC [2] methods. Data obtained was: moisture: 1) 10.97\%; 2) 14.75\%. Dry sample: 1) 89.03\%; 2) 85.25\%. Protein: 1) 57.07\%; 2) 54.09\%. Lipids: 1) 15.95\%; 2) 13.03\%. Minerals 1)3.86\%; 2) 3.98\%. Fiber: 1) $2.02 \%$; $1.55 \%$. Soluble Carbohydrates: 1) $21.10 \%$; 2) 27.33\%. Results of proximate analysis show: moisture is higher in samples collected late summer after rainy season, but proteins, lipids, minerals and fiber are higher in early, than in late summer, and soluble carbohydrates obtain by difference are higher in late, than in early summer. Cuetlas are seasonal, available from June to September, however people preserve them dry for out of season consumption. Cuetlas are good source of nutrients, their consumption can improve health and wellbeing of population of Puebla State.
\end{abstract}

Keywords: Edible Insects; Health; Larvae Cuetlas; Nutrition

\section{Introduction}

A large amount of people live in poverty due to shortage production of foods, hence they do not have adequate foodstuff supply, situation that lead them to search for other sources of food that nature provide and are not consume, due to lack of information regarding their nutritional value [3]. A possible action to overcome this problem is anthropoentomophagy, which is the consumption of insects as food, most of the times underutilized despite their high nutritional value. Entomophagy practiced since ancient times, when climate changes, and lack of food and water, resulted into the extinction of mammoths, mastodons, and the huge beasts that had provided a plenty food supply of meat, eventually became extinct as their sources of food, then the killer of beasts gave way to the collectors of anything else remotely edible, such as plants, and small animals, insects, rodents and lizards, consumed as a new source of food to supplement their diets [4]. In Mexico indigenous people have long time ago, used insects as food $[5,6]$. These food resources are an important and integral part of the subsistence strategies of many people throughout the world, insects provided an important source of proteins, lipids and minerals to population where other source of those nutrients are not available $[7,8]$. Knowledge of entomophagy is handed down through generations by oral transmission and conveys when and how to find, collect and prepare different species of insects available to be consume by population. Puebla State with a wide variety of ecology systems of cultivate and wild plants, constitute an adequate habitat for insect reproduction [9]. Cuetlas seasonal insect of Lepidoptera order, butterfly, Arsenura polyodonata, genus/specie, is consumed in larvae stage, found on pochote (Ceiba parvifolia S) and jonote (Heliocarpus appendiculatus) trees, larvae stage, are available during summer time $[10,11]$. The aim of this research is to investigate and determine their availability and assess their nutritional value to inform by means of direct communication to population the health benefits of the insect consumption and promote their inclusion in the daily diet of people living in the area studied.

\section{Material and Methods}

Sample collection

Cuetlas (Arsenura polyodonata C) insect highly distributed in Puebla State, at the flat plains of the Atlixco valley, located at center west of Puebla city, with variety wild vegetation, and warm and semi-humid climate with rains in summer time, was selected for this research. The area was previous visited to contact and get assistance of local people specialized on insect collection, since capturing these organisms request particular techniques familiar 
to them, in addition, also to determine cuetla's availability. Convenience sampling [12] was provided July 2018, and September 2018. Insects were gathered directly from the Jonote tree (Heliocarpus appendiculatus) using a wooden stick onto which the worm crawls. Insects hatch shows a green color, just before raining season, later on the color changes to dark-brown, then thorns appear in their surface which means that they are ready for consumption. Insects obtain, were washed and sun-dried, thorns then were removed by shaking them inside a paper bag. After sample collection, insects keep in dry glass containers at $4^{\circ} \mathrm{C}$ and transport by land to the Metropolitan Autonomous University-X, for further taxonomical identification [13], and nutrients analysis according AOAC [2] techniques.

\section{Determination of moisture}

Moisture content of the sample was determined by using the direct drying method. Homogenized sample $(10 \mathrm{~g})$ by size of each organism $(8 \mathrm{~cm})$ was dried in an oven Felisa (Felisa, S.A. de C.V., Jalisco. Mexico.) at $60^{\circ} \mathrm{C}$ for $24 \mathrm{hrs}$. The sample was powdered in a mortar then passed through a 60 mesh. The fine powder obtained was used for further analysis.

\section{Determination of total ashes}

Ash content of sample was determine using the dry ashing method. The sample $(10 \mathrm{~g})$ was incinerated in a cold muffle furnace Felisa (Felisa, S.A. de C.V. Jalisco, Mexico.) set at $650^{\circ} \mathrm{C}$ for 6 hrs or until whitish/greyish ash was obtained. Organic matter was burned off and the inorganic material remained was cooled and weighed. Ash solution for determination of minerals composition was then prepared by dissolved the resulting ash in $100 \mathrm{~mL}$ of $1 \mathrm{~N}$ hydrochloric acid [14], $50 \mathrm{~mL}$ were taken for the determination of sodium, potassium, calcium, iron, zinc and magnesium, contents, by atomic, absorption spectroscopy [15], using a Varian SpectrAA-250 Plus apparatus, which was calibrated with a nitric and percloric acid solution and standards according to the equipment's manual. The results expressed as mean $\mathrm{g} / 100 \mathrm{~g}$ of sample ash content, and $\mathrm{g} / 100 \mathrm{~g}$ of sample for each mineral element.

\section{Determination of Protein}

Protein content of sample was determined according to the principle of the Kjeldahl method [2]. Sample (1g) was digested with $15 \mathrm{~mL}$ of concentrated sulphuric acid using an electrically heated aluminum block digester. The resulting solution digest was diluted and then alkalinized with $50 \mathrm{~mL} 40 \%$ sodium hydroxide. This was followed by rapid steam distillation of ammonia from the diluted into $25 \mathrm{~mL}$ of $4 \%$ boric acid for manual titration with $0.2 \mathrm{~N}$ hydrochloric acid. A convention factor of 6.25 was used to convert the measured nitrogen obtain to protein content. All samples were analyzed in triplicate and the results are expressed as mean g/100 g dry basis of sample.

\section{Determination of lipids}

Lipid content determination was carried out by the semicontinuous solvent extraction method [2]. Sample $(10 \mathrm{~g})$ was extracted with $180 \mathrm{~mL}$ of petroleum ether on a Soxhlet apparatus (SigmaAldrich, Mexico, Mexico) for 10 hrs. Petroleum ether was removed content by evaporation and the residue of lipid was weighed. All samples were analyzed by triplicate and the results are expressed as mean $\mathrm{g} / 100 \mathrm{~g}$ dry basis sample.

\section{Determination of crude fiber}

Crude fiber content of the sample (2g) was performed by acid hydrolysis with $200 \mathrm{~mL}$ of a sulfuric acid solution $0.255 \mathrm{~N}$ (1.25\%) followed by alkaline hydrolysis, with a sodium hydroxide solution $0.313 \mathrm{~N}(1.25 \%)$ of sodium hydoxide in a Labconco apparatus (Labconco Corporation, Kansas City, Mo. USA). Sample was analyzed by triplicate and results expressed as mean $\mathrm{g} / 100 \mathrm{~g}$ dry basis sample.

\section{Determination of soluble carbohydrates}

Carbohydrates content on dry basis was calculated by difference, according Equation (1).

Soluble carbohydrates $=[100-($ protein + lipids + ash + crude fiber)]

\section{Results and Discussion}

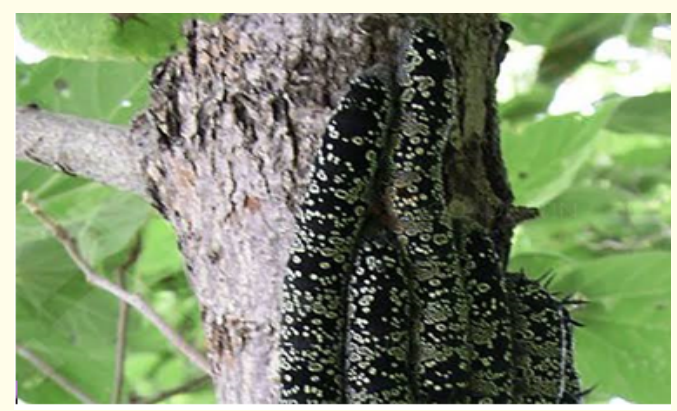

Figure 1: Image of Cuetlas (Arsenura polyodonata) from Jonote tree (Heliocarpus appendiculatus).

Sampling

Cuetlas (Arsenura polyodonata) obtained, were captured in Atlixco valley at the Jonote tree (Heliocarpus appendiculatus), but they can also be find on pochote tree (Ceiba parvifolia R), larvae insects are not available all year around, seasonal availability depends on the biotic and abiotic conditions of the environment, which is mainly during rainy season in the summer time (Table 1). However, cuetlas can be consume after season, preserved by means of different alimentary techniques, such as, drop them in boiling for few minutes and dry or toasted, and storage in dry glass containers. 


\begin{tabular}{|c|c|c|c|c|c|c|c|c|c|c|c|c|}
\hline Month & Jan & Feb & Mar & Apr & May & Jun & Jul & Aug & Sep & Oct & Nov & Dec \\
\hline Availability & - & - & - & - & - & $\mathrm{x}$ & $\mathrm{X}$ & $\mathrm{X}$ & $\mathrm{X}$ & $\mathrm{x}$ & - & - \\
\hline
\end{tabular}

Table 1: Availability of Cuetlas (Arsenura polyodonata) in 2018.

$\mathrm{X}=$ Abundant; $\mathrm{x}=$ Low; - = Not Available.

\begin{tabular}{|l|l|}
\hline Class & Insecta \\
\hline Order & Lepidoptera \\
\hline Family & Saturnidae \\
\hline Genus & Arsenura \\
\hline Species & polyodonata \\
\hline Common name & Cuetlas \\
\hline
\end{tabular}

Table 2: Nomenclature of Cuetlas (Arsenura polyodonata)

(Moron, M.A., Terron, R. 2011).

\section{Moisture}

Insects get water from environment moisture, therefore, organisms captured earlier contain less water than those harvested after the rains, at the end of the season, even though, in both cases cuetlas are low in moisture content, being almost $90 \%$ of its weight dry matter (Table 3), which means they can be storage with low risk to be spoil due to microbial grow.

\begin{tabular}{|c|c|c|}
\hline Parameter & 1) Jul 2018 & 2) Sep 2018 \\
\hline Moisture & $10.93 \%$ & $14.75 \%$ \\
\hline Dry sample & $89.03 \%$ & $85.25 \%$ \\
\hline
\end{tabular}

Table 3: Moisture determination of Cuetlas (Arsenura polyodonata).

\section{Total minerals}

Minerals most of the times are not consider as nutrients or as important elements for human nutrition, due to the low amounts requested for health maintenance, however some of them are essential in different functions of the metabolic processes, in addition they are component of tissues and blood. Deficiency can lead to several deceases, and excesses can be toxic.

\section{Individual minerals}

The minerals quantify individual were $\mathrm{Na}, \mathrm{K}, \mathrm{Ca}, \mathrm{Fe}, \mathrm{Zn}$ and $\mathrm{Mg}$, all of them with specific functions in the human body. Na and $\mathrm{K}$ are essential for transmission of electrical impulses along the nerves and for muscle contraction. Ca essential in muscle contraction, nerve impulse, regulation of fluid balance within cells and component of bones and teeth. $\mathrm{Zn}$ important for immune system, plays a role in cell division and cell grow, needed for senses of smell and taste. Fe is integral part of the blood, transport oxygen from lungs to the body tissues, deficiency leads to anemia, condition that affects many people. Mg required for energy production, regulate blood glucose levels and helps bones remain strong. (Melo-Ruiz, V., Cuamatzi-Tapia, O.) Due to the mentioned above, food mineral composition most be consider.

\section{Proteins}

Proteins are essential components for cellular and organs function, however, the diet must content not only enough protein and amino acids, but also non protein energy to permit optimal utilization of dietary protein. Protein malnutrition is very common worldwide and has severe effects on brain functions. In addition, people with protein energy malnutrition have a reduced immune function and hence are more susceptible to infectious diseases [16]. Protein requirements for men (body weight $\sim 79 \mathrm{~kg}$ ) is about $63 \mathrm{~g} / \mathrm{d}$, and for women (body weight $63 \mathrm{~kg}$ ) is about $50 \mathrm{~g} / \mathrm{d}$. In this context, cuetlas protein content acids is (Table 4) $57.07 \pm 0.6 \mathrm{~g} / 100 \mathrm{~g}$ dry sample, thus insect represent a good option of protein intake that can be consume with other nutrients, to supply protein requirements for maintaining appropriate metabolic functions for people that cannot afford for other protein sources. If protein is consumed in excess, may be transformed into carbohydrates by means of gluconeogenesis, acting mainly as energy source [17].

\begin{tabular}{|l|l|l|}
\hline \multicolumn{1}{|c|}{ Nutrient } & \multicolumn{1}{c|}{ 1) Content } & 2) Content \\
\hline Proteins & $57.07 \pm 0.6$ & $54.09 \pm 0.7$ \\
\hline Minerals & $3.86 \pm 0.3$ & $3.98 \pm 0.2$ \\
\hline Lipids & $15.95 \pm 0.7$ & $13.03 \pm 0.5$ \\
\hline Fiber & $2.02 \pm 0.3$ & $1.55 \pm 0.4$ \\
\hline Soluble carbohydrates & 21.10 & 27.33 \\
\hline
\end{tabular}

Table 4: Macro-nutrient composition of Cuetlas (Arsenura polyodonata) g/100 g dry basis.

All values are mean of triplicate determination.

Protein content $=\mathrm{N}$ determined by Kjeldhal x 6.25

Soluble carbohydrates obtain by difference according to Equation (1).

\section{Lipids}

Lipids play an important role in diverse cellular processes, such as structure and energy among others, contain more than twice the energy for gram ( $9 \mathrm{Kcal} / \mathrm{g}$ ), than carbohydrates or proteins (4Kcal/g), which explains why humans preferentially store fat as the primary energy reservoir [18].

Lipids are also source of fat soluble vitamins and sterols. Lipid consumption recommended for a daily intake, should be about $20 \%$ to $35 \%$ for a 2000 calorie diet, this represent, $56 \mathrm{~g}$ to $78 \mathrm{~g}$ of fat, or for 3000 calorie diet, this represents about 83 to $117 \mathrm{~g}$ of fat [19]. Lipids contain in cuetlas is $15.95 \% \pm 0.7 \mathrm{~g} / 100 \mathrm{~g}$ dry sample (Table 4), therefore these insects contain an adequate amount of lipids requirements for health maintenance of people living on rural areas. 
In addition, fatty acid composition of insects can be influenced by the plants on which they feed, and has been reported that edible insects contain a considerable amount of unsaturated fatty acids essential linoleic and $\alpha$-linolenic of which nutritional importance is well recognized, mainly for the health development of children [20].

\section{Fiber}

Dietary fiber is generally defined as polysaccharides that cannot be digested by human enzymes. It has been reported that the prevalence of heart disease and some cancers was associated to lack of dietary fiber consumption, therefore adequate intake of dietary fiber is important for human health [21]. In addition some types of fiber can slow glucose absorption and reduce insulin secretion, which is important for diabetics and nondiabetics as well.
The beneficial functions of dietary fiber are essential for a wellbalanced diet that will help to minimize some of the most common health problems worldwide. The dietary fiber intake recommended is $3 \mathrm{~g}$, cuetlas insects contain $2.02 \pm 0.3$ dry sample (Table 4 ), low than requirement, but in addition to other food intake, might contribute to a healthy diet.

Soluble carbohydrates

This carbohydrates group includes some of the most important molecules with multitude of functions involved in human nutrition, such as energy reserves for brain's as unique energy source, among others. Cuetlas contain $21.10 \mathrm{~g} / 100 \mathrm{~g}$ dry basis (Table 4) much lower than requirements, $60 \%$, but excess of proteins can be transformed into carbohydrates by means of gluconeogenesis, that can be used to increase requirements.

\begin{tabular}{|l|c|c|c|c|c|c|}
\hline Total minerals & Sodium & Potassium & Calcium & Iron & Zinc & Magnesium \\
\hline 1) 3.86 & 0.674 & 0.765 & 0.102 & 0.025 & 0.018 & 1.752 \\
\hline 2) 3.98 & 0.598 & 0.701 & 0.089 & 0.021 & 0.016 & 1.692 \\
\hline
\end{tabular}

Table 5: Mineral composition of Cuetlas (Arsenura polyodonata) g/100 g dry basis.

Not all minerals were identify and quantify

\section{Conclusion}

Cuetlas insects, consume as larva stage of a butterfly, are a rich natural food, source of some macronutrients essential in human health, provide high amount of proteins and lipids, minerals should be consider, because of the important role they play in health, are low in fiber and soluble carbohydrates but in combination with other sources of food from the diet, these components can provide balanced amount of nutrients, are well accepted and consumed by local people that can be benefit, and improve their health in Puebla State and other zones with similar environment conditions, such as Veracruz and Guerrero States. Nutritional value of insects can vary according biotic and abiotic condition of the environment. Insects are seasonal but with support of adequate alimentary techniques they can be storage for out of season consumption. They are available to people that cannot afford other source of macronutrients rich in proteins, such as different kind of meats or fish. Moreover, commercialization of these insects could increase the economic status of poor inhabitants of the zone and in other regions where cuetlas are available.

\section{Competing Interests}

Authors have declared that there is no conflict of interests exists.

\section{Bibliography}

1. Castelle-Iturbide T. "Presencia de la comida prehispánica". Fomento Cultural Banamex, A.C. Mexico City, Mexico (1986).

2. AOAC. "Official methods of analysis". $16^{\text {th }}$ edition. AOAC International. Washington, DC (1995).
3. Chavez A and Chavez M M. "The Nutritional Impact in Human Health and Functional Capacity”. In National Institute of Medical and Nutritional Sciences, Salvador Zubiran. Mexico (2009).

4. Meyer MC and Sherman WL. "The course of Mexican History". Oxford University Press, Inc. New York, USA (2003).

5. Sahagun FB. "Historia General de las Cosas de la Nueva España”. Archivo General de la Nacion. Mexico (1988).

6. Sahagun FB. "Codice Florentino”. Archivo General de la Nación. Mexico (1980).

7. Kuhnlein H V. "Macronutrient Nutrition and Traditional Food Systems of Indigenous Peoples". Food Nutrition and Agriculture 32 (2003): 33-39.

8. DeFoliart G. "Insects as Food: Why the Western Attitude is Important". Annual Review of Entomology 44 (1999): 21-50.

9. Speight MR., et al. "Ecology of Insects. Concepts and applications". $1^{\text {st }}$ edition. Blackwell Science, Ltd. London, UK (1999).

10. Melo-Ruiz V., et al. Journal of Agricultural Science and Technology A 6 (2016): 423-428.

11. Melo-Ruiz V., et al. "Biochemistry of the Metabolic Processes". $3^{\text {th }}$ edition. Editorial Reverte. Barcelona, España (2019).

12. Greenfield H and Southgate DAT. "Food Composition Data". $2^{\text {nd }}$ edition. FAO, Rome (2003). 
13. Moron MA and Terron R A. "Entomología Práctica”. Instituto de Ecología, Mexico (2011).

14. Curry ASR and Kontt AR. "Analyst Flame Atomic Absorption Spectrometry Analytical Methods" (1969).

15. Tee ES., et al. "Laboratory Procedures in Nutrition Analysis of Food”. Kuala Lumpur, Malaysia (1996).

16. Pencharz PB. "Protein and Amino". In Present Knowledge in Nutrition. $10^{\text {th }}$ edition, edited by Erdman,JW, Macdonald IA, and Zeisel SH. Wiley-Blackwell, Iowa, USA (2012).

17. Mahan LK and Escott-Stump S. "Nutrition and Diet Therapy of Krause". $9^{\text {th }}$ edition. McGraw Hill. Mexico (1998).

18. FAO. "Fats and fatty acids in human nutrition: report of an expert consultation". FAO Food and Nutrition Paper. Rome (2010).

19. Lichtenstein AH and Jones PJH. "Lipids: Absorption and Transport". In Present Knowledge in Nutrition. $10^{\text {th }}$ edition, edited by Erdman JW, Macdonald IA, and Zeisel SH. Wiley-Blackwell, Iowa, USA (2012).

20. van Huis A., et al. "Edible Insects Future Prospects for Food and Feed Security”. $1^{\text {st }}$ edition. FAO. Rome (2013).

21. Johnson IT. “Dietary Fiber”. In Present Knowledge in Nutrition. $10^{\text {th }}$ edition, edited by Erdman JW, Macdonald IA and Zeisel SH. Wiley-Blackwell, Iowa, USA (2012).

\section{Volume 3 Issue 10 October 2019}

(C) All rights are reserved by Virginia Melo-Ruiz., et al.. 